\title{
Student Self-Responsibility in The Indonesian Distance Education System
}

\author{
D. Lazarus $^{1}$
}

\begin{abstract}
An ongoing concern in the distance education system in Indonesia is students' lack of commitment to 'independent study'. The purpose of this paper is to review conceptual frameworks that could empower Indonesian students to accept responsibility for their learning at a level to address the learning challenges of distance education. The review shows that to meet quality and equity expectations in online distance education, independent study modes should promote students' self-responsibility based primarily on both autonomy and capability. The findings have the potential to add new perspective to education through supporting teaching and learning approaches in an online distance education class to enhance self-responsibility. The paper suggests that students would take more control of independent learning if they accepted primary responsibility to determine their learning needs, resources, activities and outcomes. To do this they need to view themselves as active agents with power to take independent choices that can result in creating their own approaches to resolve their learning limitation
\end{abstract}

Keywords: independent study, self-responsibility, student autonomy, distance education, the indonesia open university

\section{Introduction}

Distance education (DE) - described as the various forms of study, at any level, not led by the physical presence of a teacher in class-rooms (Harry et al., 2013) - has become a viable alternative for almost anyone who wants to enhance their skills and knowledge without being constrained by time and location. For example, Zuhairi et al. (2006) highlighted the successful implementation of Indonesian DE courses, which aimed to improve the quality of Indonesian teachers in the rural areas of Kalimantan, Sulawesi, Maluku and Papua. These DE courses have been known as Sistem Pendidikan Tinggi Terbuka Jarak Jauh (PTTJJ) and only available through the Indonesia Open University or 'Universitas Terbuka' (UT). In recent years, therefore, DE programs in UT have become widespread, particularly in rural areas of Indonesia. In 2014, for instance, the distance courses offered by UT had 426,503 enrolled students, most of whom were working adults (Arifin, 2016a) who are unable to follow conventional study schedules due to their personal circumstances (e.g. economic situation, family, disability and illness) or work obligations.

Several studies in Indonesia have examined the benefits of DE for those who live in rural areas and for the poor. Benefits such as a cost-effective form of learning or reduce the cost of learning components (Islam, 2015); increase student's digital literacy (Zubaidah, 2013) and provide opportunities for adult workers who are unable to attend

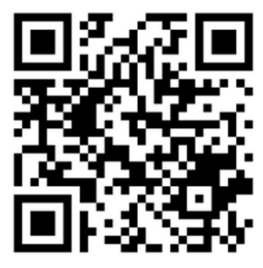

Department of Electrical and Information Engineering, Pontianak State Polytechnic (POLNEP), West Kalimantan, Indonesia EMail

d.lazarus@polnep.ac.id

This paper was presented in the 5th Indonesian Student International Conference (KIPI-2016), PPIA, Adelaide, 8-9 April 2016

Submitted November 2017 Accepted : Desember 2017

JAS-PT

JURNAL ANALISIS SISTEM PENDIDIKAN TINGG ISSN 2580 - 5339

Volume 1 Nomor 2

DESEMBER 2017 Hal $69-78$

FORUM DOSEN INDONESIA 
Acknowledgement

The author would like to thank

the Indonesian Ministry of

Research, Technology and

Higher Education

(KEMENRISTEKDIKTI) for

making this research possible

through the Directorate

General of Higher Education /

DGHE's financial support.

a traditional learning setting need to be considered against the problems of practice, which found to be: the challenging population and geographical situation (Zuhairi et al., 2006), the communication and transportation infrastructure limitation (Chandrawati, 2015), student low persistency (Arifin, 2016a) and student low willingness to be an independent learner (Lazarus and Ferris, 2014). Correspondingly, this paper specially focuses on students' sense of Self-Responsibility (SR) in developing the independency within DE learning process.

This paper provides a review of conceptual frameworks that could be used to assist Indonesian students to accept SR for their learning process at a level sufficient to develop the independency in DE. The first section discusses the theoretical frameworks. The second section focuses on the Indonesian DE system. The third section offers a discussion of ways to promote students' sense of SR in the Indonesian DE system.

\section{Literatures Study}

\section{Self-Responsibility in DE systems}

The study of SR originated from the idea of 'self-directed learning' (SDL) in adult environment in which students/learners take the primary responsibility either in the method or the outcome or the content of education (Lazarus and Ferris, 2016a). SDL were initially defined as a process where 'individuals take the initiative, with or without the help of others, in diagnosing their learning needs, formulating learning goals, identifying human and material resources for learning, choosing and implementing appropriate learning strategies and evaluating learning outcomes' (Knowles, 1975, p. 18). From this definition, researchers - such as: Guglielmino and Guglielmino, Brockett and Hiemstra, Candy, Brookfield, etc. - have provided a further definition of SDL from different perspectives. For example, Brookfield (2012) considered SR as a cognitive process grounded in reflection and action of an individual to achieve his/her learning goals. Thus, by taking over the learning responsibility, students could develop the ability to reflect on their current position in the learning process (Lazarus and Ferris, 2016a). This reflection allows students to address their learning develop their own approaches to improve their weaknesses weakness in particular areas and develop their own approaches to improve their weaknesses. Therefore, the notion of SR encompasses both the capability of a learner to set their own pace and to put a personal structure on their learning (Lazarus and Ferris, 2016a).

Meanwhile, independent study for DE at university level was initially defined by Charles Wedemeyer who described an independent learner as "a person not only independent in space and time but also potentially independent in controlling and directing learning" (Moore and Kearsley, 2011, p.222). For Wedemeyer, the essential characteristics of the independence of the learner are flexibility to learn without being constrained by time and location; greater student responsibility for learning; focus on educational tasks; widely available instruction; effective mix of media and methods; adaptation to individual differences; provision of evaluations of student achievements and the freedom to start and stop the learning process at any time (Holmberg, 2005).

JAS-PT

JURNAL ANALISIS SISTEM PENDIDIKAN TINGGI

ISSN 2580 - 5339

Volume 1

Nomor 2

DESEMBER 2017

Hal $69-78$

FORUM DOSEN INDONESIA
A study of student autonomy in DE contexts was conducted by Michael Moore who described the role of DE students in doing their learning with a minimum of teacher provided help. Learning autonomy, according to Moore, is "the will and the ability to exercise powers of learning, to overcome obstacles for oneself, to try to do difficult learning tasks and to resist coercion" (Moore, 1973, p. 667). Thus, the power of 
'autonomy' is expressed in a process where learners, not the teacher, determine the goals, learning experience and evaluation decisions of their learning program (Moore and Anderson, 2003).

Since autonomy is a learning process, affected by learner's situation or environment, especially when learners are feel familiar with their learning environment or in areas that are similar to their prior experience (Candy, 2004), then several DE studies around the world have underlined the merits of re-designing DE systems based on 'local culturally appropriate pedagogy' with an advanced learning environment that support students to be independent learners. For example, Behrend (2005) suggest that when DE providers design a distance learning environment, the efforts aimed at extending quality of the program to all students ironically often failed to support students who came from different cultural backgrounds. By forcing students to accept the concept of SR without considering learner's cultural orientation might meet with resistance, particularly from those who are culturally raised within an oral tradition or for those who perceive themselves as technologically-illiterate (Toha, 2015)

In contrast to those socio-cultural arguments, several studies have highlighted the successful implementation of contextual approaches to promote learning style adjustment in DE systems. Wong (2004), for instance, argues that contextual approaches will provide an opportunity for distance learners to adjust their learning style to meet the requirements of a new learning environment. Clardy (2000) notes when the external characteristics of instructional processes require learners to change their paradigms on how their learning style could fit into the environment, the shifting paradigm can create new self-responsible behaviours in the individual. These new behaviours could be expressed through the awareness of their role in learning processes and progress.

From those point of views, we could understand that the capability of learners to be independent within DE learning process is depended on their willingness to take over the ownership over learning which, unfortunately, is not well adopted by every student. The quasi-permanent separation between teachers and learners in DE system empowers learners to control their learning process, although, the capability to be the owner of learning process could be achieved if learner has constructed sense of SR. This construction, through self-reflection process, will affect learner's perspectives and capacity of control in managing their own learning process. In a study of the impact of online tutorials in Indonesia, Belawati (1998) found that students' active participation have a positive correlation with course completions rates and academic achievement.. Similarly, a study of student success factors in Indonesian DE by Toha (2015) also found that students' autonomy is the important factor in determining student's academic success. Through this point of view, learner has a responsibility - stipulated by the willingness to take over the ownership of learning process - to develop a series of skills/competencies that needed to cope well in his/her real life or future careers (Lazarus and Ferris, 2016a).

In the regard of an individual willingness, the attention of 'independency' in SR is given to the different interests of an individual in accepting responsibility for their learning process and progress. As knowledge cannot be taught but constructed from learner's interpretation of events and ideas (Candy, 2004), then SR is constructed from the learner's past educational experiences and affected by the capacity of the 'agent' to act freely (Lazarus and Ferris, 2016a). In the regard of the construction, Moore and Kearsley noted, 'every learner has to construct knowledge through a process of personally accommodating information into previously existing cognitive structures. It is
JAS-PT

JURNAL ANALISIS SISTEM PENDIDIKAN TINGG

ISSN $2580-5339$

Volume 1

Nomor 2

DESEMBER 2017

Hal $69-78$

FORUM DOSEN INDONESIA 
interacting with content that results in these changes in the learner's understanding' (2000, p. 128). Moreover, the notion of agent refers to the sense that an individual has ownership of action within thinking capability and becomes the trigger to individual's affective motivation and behaviour (Bandura, 2001). This ownership is expressed through activities to practice SR in making critical judgments about a range of tasks and functions with minimal guidance from teachers (Lazarus and Ferris, 2016a).

Another aspect of SR is related to students' capability to manage the perceived barriers in DE systems. If the construction of SR is determined by the external characteristics of teaching-learning process (Hiemstra and Brockett, 2012), of interest is to determine how SR is developed or exercised within constraining learning environment. Distance educators have focused on learning situations that tend to promote SR (Guglielmino and Toffler, 2013) and the characteristics which influence students' dependence/independence learning behaviours (Brookfield, 2012). In this regard, a research on Hong Kong DE students in nursing program showed that field-dependent (FD) learners are influenced by their physical and social background. When confronted by barriers, therefore, they are less ready for unpredictable situations. However, these students could change to be field-independent (FI) learners by shifting the cognitive structures (Ching, 1998). Cognitive changed refers to the development of new neural connections where learners are able to construct and confirm meaning (Setiani and Mackinnon, 2015).

The concept of FD and FI in DE was also utilized by Chapelle and Heift (2013). They distinguished FI learners as self-directed, logical, analytical and independent. As learner's responsibility increases, FI learners would show a higher degree of control over the planning and management of their learning; they would effectively locate and use a variety of resources; they would be able to organize and make the best possible use of time; they would see themselves as competent and effective and would be confident in their ability to direct their own learning (Lazarus and Ferris, 2016a).

Collectively, we use SR to mean the idea that students take responsibility for identifying, planning and addressing any learning limitations which they may have. Hence, the term of SR is defined as a self-determined process to a certain degree that a learner, as the centre of the development process, accepts personal responsibility, along with its consequences, to identify, plan and address any development limitations which he/she may have by developing a series of competencies needed to manage well in his/her real life or future career (Lazarus and Ferris, 2016b). In corresponding to this definition, we encompasses both the capability of a learner to set their own pace and to put a personal structure on their learning (Lazarus and Ferris, 2016a).

\section{The Result of Study}

Nature of the Indonesian DE system

Providing an equality of education for all 250 million Indonesian citizens, spread across over 17,000 islands, with a limited communication and transportation infrastructure, has been challenging for the Indonesian government, particularly the Ministry of Research, Technology and Higher Education (Kemenristekdikti). The establishment of DE which could be accessed by everyone from any place in Indonesia is the government response intended to enhance equality of opportunity for high quality HE (Chandrawati, 2015). To show their concern to the equality issue, therefore, the Indonesian government through the Directorate General of Higher Education (DGHE) launched a 
program called Long Term Strategy 2003-2010 that explicitly emphasized the role of UT in educating students in all Indonesian regions based on the five pillars of Reformasi: autonomy, accountability, equality, accreditation and evaluation (Buchori and Malik, 2004, Koning and Maassen, 2012). Through this strategy, UT as agent of reform should prepare students' future by not only focusing to knowledge transfer, but also individual personal development (Lazarus and Ferris, 2014). However, three major factors that restrict Indonesian DE students become self-responsible learners are: learning environments, the characteristic of DE learners and the misinterpretation of the concept.

\section{Learning environments}

Arifin (2016a) argues that poor learning environments with little support for students to become independent hinder the practice of SR within the Indonesian DE system. He argues that the current Indonesian DE learning environment has not addressed the various barriers to the learning process. The learning materials and supports, which were designed to provide a supportive learning environment for those with limited time for study have failed to address the diverse learning needs and styles of the whole student cohort (Arifin, 2016a). Face-to-face tutorials, for instance, are only available for students who live near the regional offices. Online tutorials give learning support for those who are unable to attend face-to-face tutorials, but this service can only be accessed by students who have internet access. The issues become more complex when students express their dissatisfaction with the teaching-learning process, particularly when they have had difficulty accessing the ICT learning resources or support.

One way to address the lack of support is to redesign the DE system based on 'cultural behaviours' of teachers and learners. The aim is to support students from different cultural backgrounds by creating culturally appropriate approaches (Behrend, 2005), particularly for those who were raised in an oral tradition or who perceive themselves as technologically illiterate (Toha, 2015). Therefore, Arifin describes the advantage of using the learner's cultural orientation in DE as: 'once students see college as an important aspect of their lives, they are better able to create symbols that help them conceptualise how to better manage their behaviour, the environment, and the personal and cognitive factors that impact their ability to succeed in college' (2016a).

\section{The characteristic of DE learners}

Typically, Indonesian DE learners are influenced by the oral tradition of teaching method where teachers represent authority, power and source of knowledge (Zubaidah, 2013). Within this traditional learning perspective, learners are characterized by obedience to follow the teacher's direction without exercising active engagement in selfresponsibility. The teacher with a higher status represents authority, power and being the source of knowledge; thus, should be the model (ditiru) and be followed (digugu) by his/her pupils (Zubaidah, 2013). The role of students in the Indonesian education system is as the receivers of knowledge who passively follow the transfer process as presented by their teacher. Therefore, students are not given chances to evaluate the learning process in ways which will help them perform tasks or confront problems in their future careers. Without this ability, it is difficult for students to develop independence in the learning process.

Student obedience follows from the element of cultural wisdom that teaches young Indonesians to obey older people or those from higher ranks of society; which, unfortunately, hinders students from being involved in deeper dialogues or discussions

\footnotetext{
JAS-PT

JURNAL ANALIISS SITTEM PENDDIKAN TINGG

ISSN 2580 - 5339

Volume 1

Nomor 2

DESEMBER 2017

Hal $69-78$

FORUM DOSEN INDONESIA
} 
when they disagree with their teachers or tutors (Zubaidah, 2013). While some literature highlighted this obedience value as one of the most common cultural traditions in Asian countries (e.g. Dardjowidjojo, 2001, Zubaidah, 2013), there are several critics that try to connect the obedience with the low capability of Indonesian DE students in performing analysis and critical thinking. For example, Toha claims that the total obedience only makes students doubted their own real capability (2015), while Belawati and Arifin note the obedience will decreasing student persistence, particularly when students facing academic difficulties (Belawati, 1998, Arifin, 2016a). By contrast, Chandrawati argues that there is no statistical data available to show that student obedience has a negative impact on their performances. She adds, however, there is a tendency related to the traditional teaching approach used by the Indonesian teachers (2015). As indicated above, within the traditional learning method, students are not given any chance to evaluate the learning process to the extent that they could use their critical consciousness for performing tasks or problems that they may confront in their future careers.

Student obedience is also related to the element of cultural wisdom that have taught the Indonesian societies to live in harmony and tolerance. The obedience to the older person or individuals from higher hierarchy society, unfortunately, hinders students from being involved in deeper dialogues or discussions whenever they disagree either with their teachers or tutors (Zubaidah, 2013). Reluctance to express a disagreement directly, Toha (2015) argues, is also caused by the indoctrination of Indonesians during the era of colonialism which has resulted in inferior mentality through forms of passiveness, shyness and fear. Given that the cultural and indoctrination have happened over generation, it is a complicated process for young Indonesians to change their learning characteristics.

Moreover, by nature, DE replaces the conventional, face-to-face, methods of interaction between teacher, student and curriculum content with information and communication technologies (ICT) based interaction and requires the students to become independent learners with only ICT enabled communication with teachers or peers. The learner's capability for autonomous study and how this interacts with DE models, ironically, is often neglected in the DE design process (Islam, 2015). The majority of UT students do not adapt well to the demands of independent learning (Dardjowidjojo, 2001). They have, generally, not yet developed awareness of autonomous learning and only reached a low level of responsibility (Islam, 2015). This capability to study independently, unfortunately, has essential impacts on students' persistence, particularly when they confront the impersonal learning of DE environment.

\section{Misinterpretation of Self-Responsibility Concept}

As DE system promotes students' independency and autonomy, many instructors misunderstand the concept of self-responsibility by not providing either any teacherstudent interactions or any clear instructions on what students should do with the given topics. As a result, students expressed their disappointment with their learning support by stating '... I need the tutor to facilitate the discussion more intensely, at least by

JAS-PT

JRNAL ANALISIS SISTEM PENDIDIKAN TINGG ISSN $2580-5339$

Volume 1 Nomor 2

DESEMBER 2017

Hal $69-78$

FORUM DOSEN INDONESIA giving us suggestions or explanations ...' (Zubaidah, 2013, p. 113). The misinterpretation was that the teachers assumed that the minimum involvement of $D E$ educators could trigger and motivate students to be autonomous, regardless of the different interests of an individual in accepting responsibility. Unfortunately, this misunderstanding has made students lose their confidence in directing their own learning. Such misinterpretations will create negative feelings of independent study. Arifin described the student's emotion as, 'when I had been following the learning at UT 
from the beginning, I became confused ... as a student, I found difficulty to consult with the tutors regarding my learning. So, in this situation, I was like the missing person' (2016b, p. 190). There is a need, clearly, to reformulate the concept of student SR within the Indonesian DE system.

\section{Discussion and Conclusion}

The concept of SR has not well adopted by Indonesian DE learners. Therefore, we argue that to become self-responsible learners, DE students should shift their cognitive structures into a certain level where they could practice SR for their learning process and progress. This shifting process, however, may not occur if learners have no confidence in their own abilities. Through this point of view, it is important for learners to have personal confidence in managing the learning process and creating alternatives to overcome the perceived barriers of DE systems. Indeed, they should be able to alter their internal negative characteristics into a paradigm where they can have the sense of SR. For Indonesian DE learners effectively eliminate these negative characteristics then the dimension of autonomy can be encouraged through self-reflection in learning. This self-reflection process will help students to develop their independent thinking skills which allow them to create their own approaches to improve their weaknesses (Lazarus and Ferris, 2016a). The interpretation of the self-reflection process not only changes their level of the existing cognitive structures but also changes their willingness to take over the learning responsibility. As the level of SR increases, the learners could possess a higher capability to control their own learning process.

Education in professional fields is often conceived by professional practitioners, and educators, in fields dominated by professional practice rather than an academic discipline, tend to conceive of what needs to be learned in terms of cognitive content which needs to be learned to certain levels of attainment. The levels of attainment are often described in terms of the kind of cognitive learning that needs to be attained in order for a degree qualification to be recognized as good. Examples of this effect are seen in reference curricula for education in particular areas professional, including (Nato, 2011) which describes course module content (Mead et al., 2010), in which only the cognitive domain of Bloom's taxonomy was considered and course content was described in terms of topic and level of cognitive attainment expected. These reference curricula contrast with Graduate Reference Curriculum for Systems Engineering (GRCSE) which remains dominated by the cognitive description of the necessary content but reflects interest in the affective domain described by Bloom's taxonomy and also frames the results of education using the 'outcomes' and 'objectives' formulation described in the Accreditation Board for Engineering and Technology (ABET) accreditation criteria (Pyster et al., 2012).

The common emphasis on the cognitive domain in the discussion of the intended learning outcomes of an education activity is short sighted because the result is course design that emphasizes teaching the content required to introduce students to the specific subject matter. This may be associated with including exercises, either to be done in the teacher supervised environment of the teaching classroom, so that students will gain a practical experience of doing tasks which build on the content presented, or in assessment, which result in the student demonstrating what they have learned to do through the educational activities to which they have been exposed. This misses the important aspect of professional education which must also characterize the student by taking, as a standard approach to problems the methods taught in the cognitive space,
JAS-PT

JURNAL ANALISIS SISTEM PENDIDIKAN TINGG

ISSN 2580 - 5339

Volume 1

Nomor 2

DESEMBER 2017

Hal $69-78$

FORUM DOSEN INDONESIA 
which happens if the education also develops the student's belief in the appropriateness and value of those methods.

The capacity for reconstructing a learning environment might be seen as the requirement to use creativity and analytical skills when DE learners confronted by the perceived barriers. This capacity is a significant factor of the dimension of capability, which underlines transformative cognitive structures in making critical judgments about a range of learning tasks and functions. Without this capacity, the learning process only generates the duplication of teacher's schematic thinking and creates low quality graduates who lack competencies, are poorly trained and un-productive (Lazarus and Ferris, 2016a). Nevertheless, DE learners do not always have full control of unpredictable conditions and uncertainties. This lack of control does not mean the process to become self-responsible learner is not actionable; therefore, focus should be given to student's responses in creating alternatives for executing their learning plan or activities, monitoring the process and evaluating the outcomes. When the alternatives are sufficient enough to overcome the barriers, students will gain confidence and would be better able to handle the next level of learning difficulties with a minimum guidance from their teachers. This concept is consistent with the expectations of professional positions, in which the person is expected to use their creativity and exercise initiative in relation to work tasks (Lazarus and Ferris, 2016a).

When students accept both dimensions: autonomy and capability, they could develop the ability to reflect on their current position in the learning process in a way in which they view themselves as active agents with the power to take self-development action choices that can result in material change to their situation (Lazarus and Ferris, 2016a). However, the term of autonomous or independent does not mean that new DE learners could work a hundred per cent in a self-directed manner when they come to DE environments. Learner and teacher are bound in a transactional relationship, which emphasizes the mutual responsibility of both parties in enhancing student confidence level toward self-responsibility. The minimum guidance from teacher will make students could achieve a higher level of SR if the students have already understood the reasons of learning. For those who having difficulties, then the role of DE educators is providing a support for their students to accept self-responsibility. The majority of UT's students have lost their confidence in directing their own learning and have preferred to be taught in the traditional way.

Accordingly, in the question of students developing SR for their learning and conduct in a DE course it is important for the educator to frame the DE instruction so that it does not just appear to be a presentation of the content of the course, along with learning and assessment tasks which result in students possibly gaining a perception that all that interests the instructor is the cognitive content. It is necessary for the course, both at the individual unit of instruction and at the whole program level to be constructed in a manner which will assist in transitioning students from their prior experience of education, most likely in face-to-face school environments, where the activity has a high teaching direction of specific work task character, to accommodate the apparent remoteness of the teacher. In the DE environment the student may perceive the teacher as remote because the teacher is not visible, usually is not available for discussion, so communication normally needs to be formulated in quite mature expressions of ideas because of the long turn-around time in the asynchronous communication environment, and the student is, likely, isolated from contact with other students, who are probably people with whom the student has no prior acquaintance with, resulting in a sense of isolation. The combination of factors just describes results in many students struggling 
with the personal discipline and motivation required to successfully complete their studies. These factors point to the importance of SR in the DE student and also to the importance of developing the student's affective engagement with the content so that the student will desire to learn and through learning to gain a foundation for all the personal benefits which flow as a consequence of education.

In summary, we have discussed several barriers and introduced several approaches that may be relevant to change Indonesian DE students become self-responsible learners. This study has the potential to enrich the implementation of the distance education system in Indonesia. We understand that the construction of SR in the Indonesian DE context is a complicated process which might takes times and efforts from all stakeholders. SR could be well adapted, however, if Indonesian DE learners could understand the importance of this concept for gaining their learning goals

\section{References}

Arifin, M. H. 2016a. Exploring Factors in Contributing Student Progress in the Open University. International Journal of Information and Education Technology, 6, 29.

Arifin, M. H. 2016b. Student Progress in the Indonesia Open University. Doctor of Philosophy, University of Southampton.

Bandura, A. 2001. Social Cognitive Theory: An Agentic Perspective. Annual Review of Psychology, 52, 1-26.

Behrend, M. 2005. Learning Advice Online: Designing Resources for Transnational Students. Language and Academic Skills in Higher Education Conference 2005. Canberra: ANU.

Belawati, T. 1998. Increasing student persistence in Indonesian post-secondary distance education. Distance education, 19, 81-108.

Brookfield, S. D. 2012. Critical theory and transformative learning. The Handbook of Transformative Learning: Theory, Research, and Practice. San Francisco: John Wiley \& Sons.

Buchori, M. \& Malik, A. 2004. The Evolution of Higher Education. Asian universities: Historical perspectives and contemporary challenges, 249.

Candy, P. C. 2004. Linking Thinking: Self-Directed Learning in the Digital Age. Australia: Department of Education, Science and Training.

Chandrawati, T. 2015. Understanding Dialogue In Distance Education: A Case Study in the Indonesian Open University. Simon Fraser University.

Chapelle, C. A. \& Heift, T. 2013. Individual Learner Differences in CALL: The Field Independence/Dependence (FID) Construct. Calico Journal, 26, 246-266.

Ching, L. S. 1998. The Influence of a Distance-Learning Environment on Students' Field Dependence/Independence. The Journal of Experimental Education, 66, 149160.

Clardy, A. 2000. Learning on Their Own: Vocationally Oriented Self-directed Learning Projects. Human Resource Development Quarterly, 11, 105-125.

Dardjowidjojo, S. 2001. Cultural Constraints in the Implementation of Learner Autonomy: The Case in Indonesia. Journal of Southeast Asian Education, 2, 309322.

Guglielmino, L. M. \& Toffler, A. 2013. The Case for Promoting Self-directed Learning in Formal Educational Institutions. SA-eDUC Journal, 10, 1-18.

Harry, K., John, M. \& Keegan, D. 2013. Distance education: new perspectives, London, Routledge.

\footnotetext{
JAS-PT
JURNAL ANALISIS SISTEM PENDIIIKAN TINGG

ISSN $2580-5339$

Volume 1

Nomor 2

DESEMBER 2017

Hal $69-78$

FORUM DOSEN INDONESIA
} 
Hiemstra, R. \& Brockett, R. G. 2012. Reframing the Meaning of Self-Directed Learning: An Updated Modeltt. Adult Education Research Conference.

Holmberg, B. 2005. Theory and Practice of Distance Education, New York, Routledge.

Islam, S. 2015. Kesiapan Belajar Mandiri Mahasiswa UT Dan Siswa SMA Untuk Belajar Dengan Sistem Pendidikan Tinggi Terbuka Dan Jarak Jauh Di Indonesia. Jurnal Pendidikan Terbuka Dan Jarak Jauh, 11, 1-14.

Knowles, M. S. 1975. Self-directed Learning, New York, Cambridge books.

Koning, J. \& Maassen, E. 2012. Autonomous Institutions? Local Ownership in Higher Education in Eastern Indonesia. International Journal of Business Anthropology, 3,54 .

Lazarus, D. \& Ferris, T. L. J. 2014. Assessing The Roles of Indonesian Vocational Education and Training to Increase Student's Employability. 4th Indonesian Student International Conference (KIPI-2014). Canberra: PPIA.

Lazarus, D. \& Ferris, T. L. J. 2016a. Assessing Self-Responsibility in Employability Competencies Development among Australian Engineering Students: Introductory report. 2016 International Conference on Industrial Engineering and Operations Management Kuala Lumpur: IEOM.

Lazarus, D. \& Ferris, T. L. J. 2016b. Assessing Student Self-Responsibility in The Indonesian Distance Education System. The 5th Indonesian Student International Conference (KIPI-2016). Adelaide: PPIA.

Mead, N. R., Allen, J. H., Ardis, M. A., Hilburn, T. B., Kornecki, A. J., Linger, R. C. \& Mcdonald, J. 2010. Software Assurance Curriculum Project Volume I: Master of Software Assurance Reference Curriculum. Software Engineering Institute, Carnegie Mellon University.

Moore, M. G. 1973. Toward A Theory of Independent Learning and Teaching. The Journal of Higher Education, 44, 661-679.

Moore, M. G. \& Anderson, W. G. 2003. Handbook of distance education, Mahwah, Erlbaum.

Moore, M. G. \& Kearsley, G. 2011. Distance Education: A Systems View of Online Learning, Belmont, Thomson Wadsworth.

Nato. 2011. Generic Officer Professional Military Education Reference Curriculum [Online]. Office of the Commander, Canadian Defence Academy. Available: http://www.nato.int/nato_static/assets/pdf/pdf_topics/20111202_Generic-OfficerPME-RC.pdf [Accessed 12 April 2016].

Pyster, A., Olwell, D., Ferris, T., Hutchison, N., Enck, S., Anthony, J., Henry, D. \& Squires, A. 2012. Graduate Reference Curriculum for Systems Engineering (GRCSE). Hoboken, NJ, USA: Trustees of the Stevens Institute of Technology.

Setiani, M. Y. \& Mackinnon, A. M. 2015. A Community of Inquiry Based Framework For Civic Education at Universitas Terbuka, Indonesia. Distance education, 36, 351363.

Toha, M. 2015. A Study of Student Success Factors in Distance Education at the Open University of Indonesia. Simon Fraser University.

Wong, J. K. 2004. Are learning styles of Asian international students culturally or contextual based? International Educational Journal, 4, 154-166.

JAS-PT

JURNAL ANALISIS SISTEM PENDIDIKAN TINGGI ISSN 2580 - 5339

Volume 1

Nomor 2

DESEMBER 2017

Hal $69-78$

FORUM DOSEN INDONESIA
Zubaidah, I. 2013. Evaluating the Implementation of the Online Tutorial For the Universitas Terbuka Distance Learning Bachelor Degree Program in Indonesia. The Florida State University.

Zuhairi, A., Wahyono, E. \& Suratinah, S. 2006. The historical context, current development, and future challenges of distance education in Indonesia. Quarterly Review of Distance Education, 7, 95. 